\title{
TREATIES NoBOdy COUNTED ON
}

\author{
R P Boast*
}

This article is based on the author's inaugural professorial lecture delivered at Victoria University of Wellington in March 2011. The author's subject is treaties and treaty-like agreements, entered into between the New Zealand government and Māori after the Treaty of Waitangi.

In the early 1880 s there was a prolonged process of negotiation between representatives of an indigenous and autonomous Polynesian state; a state which a prominent New Zealand historian has described as being "two thirds the size of Belgium" which "not all historians have noticed". ${ }^{1}$ This autonomous state had its own monarch, a port of its own, and was actively trying to build its economy, manage its own lands, and develop overseas trade and commerce. The process of negotiation took a number of years, involved frequent consultations at the highest level, was embodied in a number of documents, and was given effect to in legislation. To this day, those negotiations and the agreements that came out of them remain pivotal to the indigenous groups affected and are well-remembered. I am speaking of the King Country, and the negotiations that took place in the 1880s in which two Native Ministers, John Bryce and John Ballance, were involved, as well as King Tawhiao and a number of leading rangatira of the Ngāti Maniapoto, Ngāti Raukawa and other tribes. ${ }^{2}$ The historian I have referred to is of course Professor James Belich, who at the end of his The New Zealand Wars, expressed his puzzlement that the persistence of this independent Māori state in the middle of the North Island could remain off the historical radar for so long. It covered perhaps as much as 7,000 square miles, or one-sixth of the North Island: "quite a large 'isolated pocket"' as Belich puts it. ${ }^{3}$ My questions arise out of my own speciality of legal history. What should we call the process of negotiation and discussion that resulted in this

* Professor, Victoria University of Wellington. For a fuller and more comprehensively referenced discussion of the issues addressed here see my "Recognising Multi-Textualism: Rethinking New Zealand's Legal History" (2006) 37 VUWLR 547.

1 James Belich The New Zealand Wars and the Victorian Interpretation of Racial Conflict (Penguin, Auckland, 1988) at 306.

2 There is no one single text that can be said to be "the Aotea agreement". For references to the main documents see Richard Boast "Recognising Multi- Textualism: Rethinking New Zealand's Legal History" (2006) 37 VUWLR 547 at 562-565.

3 James Belich The New Zealand Wars (Auckland University Press, Auckland, 1986) at 306. 
autonomous indigenous political formation becoming a part of the New Zealand state? And what should we call the agreement that came out of the discussions? Can it meaningfully be called a 'treaty'? What, after all, is a 'treaty'? Did the term even have a fixed and definitive meaning in the middle of the 19th century? And what consequences might flow from all of this?

I am not sure what all of the answers are, but these questions are indeed assuming a new importance for reasons that I will examine later. I am not the only historian who is pondering this problem. Dr Vincent O'Malley has written a number of articles and research reports grappling with this very issue, and it is now assuming increasing importance in a number of Waitangi Tribunal inquiries. ${ }^{4}$ It is important to convey some idea of the scale of what is under discussion. In New Zealand, we have become conditioned to think of ourselves as a country where essentially there is just one 'treaty' between the Crown and the Māori people of New Zealand, that is the Treaty of Waitangi. When it comes to treaty-making we are, forgive the expression, 'uni-textual'. There is just one document that matters. That means, again supposedly, that we are radically different from, say, the United States and its colonial predecessors (the Spanish, Dutch, French, and British colonial empires), where there were literally hundreds of treaties between various empires and republics and the Indian nations. Indeed there are so many agreements of that kind in North America (running into the thousands) that - not withstanding much outstanding research - it has proved impossible to say exactly how many there are. If we are 'uni-textual' the United States is 'multi-textual'. New Zealand is different, it is assumed. But - and this is the question I want to pose - is it?

In fact, the colonisation of New Zealand was accompanied by a vast wealth of written agreements. How many of these there are is hard to know. There are certainly hundreds, and perhaps thousands of these documents. Agreement-making and the negotiations that result from agreements are as important in the history of colonial expansion as conflict, as historians from all over the world are beginning to emphasise, in countries as diverse as the United States, Argentina and - at least for one extraordinary episode - Australia. Agreements and deals are as characteristic of 19th century frontiers as battles, perhaps even more characteristic. ${ }^{5}$

One objection might be that the kinds of agreements that took place in, say, 19th century United States or Argentina are different in kind from the agreements that were made in colonial New Zealand after the Treaty of Waitangi. In fact in terms of the substance of what was agreed, they are not. Most of the 'treaties' with the Indian nations of the territories which now make up the United States were land transactions - where land was ceded, reservations identified, and the consideration

4 See Vincent O'Malley "Treaty-making in Early Colonial New Zealand" (1999) 33 NZJH 137, reprinted in Judith Binney (ed) The Shaping of History (Bridget Williams Books, Wellington, 2001) 129. See also James Belich Making Peoples: A History of the New Zealanders from Polynesian Settlement to the End of the Nineteenth Century (Allen Lane, Auckland, 1996) at 202.

5 For a comparative study see Marcia Langton and others (eds) Honour Among Nations? Treaties and Agreements with Indigenous Peoples (Melbourne University Press, Melbourne, 2004). 
for the agreement were set out and embodied in a document, usually written only in English. These documents now have the status of 'treaties' in United States public law. ${ }^{6}$ Yet in terms of their substance they are no different from the various transactions and deeds by which the Crown extinguished customary titles to land in the South Island and in much of the North in the first two decades after the Treaty. The content of, for instance, the Canterbury purchase in the South Island or the Ahuriri deed signed at Napier in 1851 are more or less the same as was standard with treaties made at the same time in the United States. In the New Zealand case the documents are, moreover, invariably in English and in Māori, making them somewhat more treaty-like than their North American counterparts. The difference lies not in the content, but in what we choose to call them. Land transactions, however, are not the only kinds of agreements that are in issue.

Before progressing further with names and labels and legalities it is necessary to focus more closely on the kinds of agreements and negotiations that occurred in the 19th century and try to clarify our thinking about them a little more. For these agreements and deals are not of the same kind and character. In fact, they are exceptionally diverse. These agreements range from very small purchases of small blocks of land from Māori by the government's land purchase officers at one end of the spectrum to the very elaborate lengthy high-level negotiations concerning the formerly independent King Country or Te Urewera at the other. It is easy to see at least that the King Country negotiations are more 'treaty-like' than, say, a simple conveyance of a few dozen acres of land at the other end of spectrum. Some kind of analysis or classification is called for. Looking over the period from 1840-1900 as a whole there are four main classes of agreements. These are: (a) pre-emptive purchase agreements; (b) peace negotiations after the New Zealand Wars; (c) confiscation agreements; and (d) regional political agreements. I wish I could think of more elegant or less clunky terminology to analyse them. My main focus will be on the last of these, but first I need to traverse the other three categories.

By far the most common form of formal Crown-Māori agreement was what we call the preemptive purchase deed dating from before the establishment of the Native Land Court in 1862. There were (probably) thousands of these agreements, and even within this category of written agreement there is a significant degree of variation. ${ }^{7}$ Some relate to thousands of square miles,

6 For a general survey, see Wilcomb E Washburn (ed) Handbook of North American Indians Volume 4: History of Indian-White Relations (Smithsonian Institution, Washington DC, 1988), especially the chapters by Dorothy Jones (at 185-194), Robert Kuasnicka (at 195-201) and Robert Surtees (at 202-210). Illustrative cases include United States $v$ Winans (1905) 198 US 37; United States v State of Washington (1974) 384 F Supp 312 (WD Wash, 1974).

7 The best-known of the early pre-emptive deeds are the Ngai Tahu (all South Island) deeds of 1844-1864, which were considered fully by the Waitangi Tribunal in its Ngai Tahu Report (WAI 27, 1991); on these deeds, see also HC Evison Te Wai Pounamu: The Greenstone Island: A History of Southern Māori during the European Colonization of New Zealand (Aoraki Press, Wellington, 1993); HC Evison The Long Dispute: Māori Land Rights and European Colonisation in Southern New Zealand (Canterbury University Press, Christchurch, 1997); HC Evison (ed) The Ngai Tahu Deeds: A Window on New Zealand History 
others to a few acres. The best-known of these deeds are the Ngai Tahu deeds of 1844-1864, the primary focus of the Waitangi Tribunal's Ngai Tahu report of 1991. These deeds related to vast areas, for example most of Otago, or all of Canterbury inland to (arguably) the southern Alps. There was another sequence of these deeds or agreements in the northern South Island from 1847-1853, including the Wairau deed of 1847 and the Te Waipounamu deeds of 1851-1853, which were negotiated with other South Island iwi, including Ngāti Toa, Ngāti Rarua, Ngāti Koata, Te Ati Awa, Rangitane and other groups, also relating to very large areas. The three huge Hawke's Bay deeds of 1851 (Waipukurau, Ahuriri, Mohaka) are similar. However there were many much smaller transactions as well.

The second category, a most amazingly neglected one, are the negotiations that brought the New Zealand Wars to an end in various parts of the country and led to the cessation of hostilities. We have a wealth of literature about the New Zealand Wars but not so much on how and why they came to an end. The New Zealand Wars were ended by negotiation. Much more needs to be learned about this. In 1869 the Native Minister in the Fox-Vogel Government, Donald McLean, travelled to the King Country where he met Rewi Maniapoto and Tamati Ngapora, King Tawhiao's principal adviser, and it was agreed that the wars between the supporters of the King and Queen should end (and nor should they ever resume). ${ }^{8}$ I do not know of any comprehensive historical study of these obviously important negotiations, although they are mentioned in Sir Keith Sinclair's book Kinds of Peace ${ }^{9}$ and in Ray Fargher's biography of McLean. ${ }^{10}$ New research now being conducted for the Waitangi Tribunal's Rohe Potae/King Country inquiry may help us to understand these negotiations rather better. McLean also held discussions with Tuhoe in 1871-1872, negotiations that led to the ending of hostilities in this region. Professor Judith Binney, who writes that in November 1871 "the government confirmed a compact with the leading Tūhoe chiefs" has also argued that at this time

(Canterbury University Press, Christchurch, 2006). The pre-emptive purchase deeds used in the northern South Island were considered at length in the Waitangi Tribunal's report released in 2008: Waitangi Tribunal Te Tau Ihu o Te Waka a Maui (WAI 785, 2008), which dealt also with the history of the Native Land Court in this region. On pre-emptive purchasing and pre-Treaty purchases in Wellington see Waitangi Tribunal Te Whanganui a Tara me ona Takiwa (WAI 145, 2003). For pre-emptive purchasing in Northland and the Coromandel see Waitangi Tribunal Muriwhenua Land Report (WAI 45, 1997); The Kaipara Report (WAI 674, 2006); The Hauraki Report (WAI 686, 2006).

8 For a brief discussion of McLean's negotiations see Richard Boast Buying the Land, Selling the Land: Governments and Māori Land in the North Island 1865-1921 (Victoria University Press and Victoria University of Wellington Law Review, Wellington, 2009) at 136-137.

9 Keith Sinclair Kinds of Peace: Mãori People After the Wars 1870-1885 (Auckland University Press, Auckland, 1991) at 49.

10 See Ray Fargher The best man who ever served the crown?: A Life of Donald McLean (Victoria University Press, Wellington, 2007) at 310. I also discuss these negotiations briefly in my Buying the Land, Selling the Land: Governments and Māori Land in the North Island 1865-1921, above n 8, at 136. 
McLean formally recognised Te Urewera's regional autonomy. ${ }^{11}$ McLean has a mixed reputation amongst New Zealand historians, but at the time he was regarded, even by his political enemies, as someone who had done much to bring about inter-racial peace. When McLean died, John Sheehan, a personal and political enemy, said to the House of Representatives that "sinking all party feeling, it would be unfair to deny that to Sir Donald McLean we are largely indebted for the fact that from 1869 up to the present time we have been at peace with the Native people". ${ }^{12}$ "Largely at peace", Sheehan should have said (he was forgetting about the conflict with Te Kooti, which lasted until 1872).

These agreements may have been partly or principally oral of course: I do not mean to confine an examination of agreement-making to written agreements. Also there were inter-Māori peace negotiations during the wars as well. If Māori once were warriors, they also once were diplomats: many great chiefs were famed for their skills as negotiators and peacemakers. This tradition continued throughout the years of the New Zealand Wars. One example of such an arrangement, also brought to our attention by Professor Binney, was the agreement between Te Keepa of Ngāti Apa, an important government ally, and the Tuhoe chief Tamaikoha in 1870, a peace nearly wrecked by a precipitate attack by Henry St John on Tamaikoha's people after the agreement had been made, to general consternation (McLean dismissed St John from his command). ${ }^{13}$ To return to the main point here, far more historiographical energy has been devoted to how the wars were started and how they were fought than to how they were stopped.

The third category of agreement is the confiscation agreement. ${ }^{14}$ Confiscation and agreement do not seem to be words that can go meaningfully together, but it needs to be remembered that the New Zealand Wars of the 1860s were also a Māori civil war, a prolongation of earlier conflicts, and the Crown needed Māori allies and supporters. In 1863 the government decided to embark on a course of punishing 'rebel' Māori by confiscating their lands and then regranting them either to 'loyal' Māori or to settlers, the latter often being pensioned-off soldiers. ${ }^{15}$ This highly coercive system had some parallels with Crown policies in Ireland, always a handy source of coercive precedent within the British Empire, and a dubious precedent too, as some of the critics of the programme in New

11 Judith Binney Encircled Lands (Bridget Williams Books, Wellington, 2009) at 203 and 206 respectively.

12 (1877) 27 NZPD 233

13 Judith Binney Encircled Lands, above n 11, at 164-165.

14 On confiscation in colonial New Zealand see generally Richard Boast and Richard Hill (eds) Raupatu: The Confiscation of Mãori Land (Victoria University Press, Wellington, 2009); PG McHugh, Richard Boast and Mark Hickford Law and Confiscation: Essays on Raupatu in New Zealand History (Treaty of Waitangi Research Unit, Stout Research Centre for New Zealand Studies, Wellington, 2010).

15 The statutory vehicle for this policy was the New Zealand Settlements Act 1863. On the military settlement programme in one confiscated area (Tauranga) see Evelyn Stokes A History of Tauranga County (Dunmore Press, Palmerston North, 1980) at 87-103. 
Zealand were not slow to point out. Sir William Martin, retired Chief Justice, published a pamphlet in Auckland in 1863 where he remarked that "[t]he example of Ireland may satisfy us how little is to be effected towards the quieting of a country by the confiscation of private land": all it did was to create a "brooding sense of wrong" leading to endless outbreaks of "fresh disturbance and crime". ${ }^{16}$ In Britain, the Aborigines Protection Society must have had had recent events in Ireland equally in mind when it wrote a letter of protest to Grey in January 1864: confiscation, Grey was sternly told, only adds "fuel to the flame of War" and would produce in New Zealand the same "bitter fruits" as found in other countries "where the strife of races has perpetuated through successive generations; and that, too, with a relentless and cruelty which have made mankind blush for their species". ${ }^{17}$ Grey, who knew Ireland well, would certainly not have missed the allusions here. Confiscation in Ireland is the subject of a well-developed literature, which tends to emphasise the wide gaps between colonial theory and intricate local realities. ${ }^{18}$ Just as in Ireland, confiscation in reality in our isles was very different from confiscation on the statute book and became a very confused and messy business at the local level. Often the result was that in a number of instances the Crown entered into agreements with Māori as a way out of the impasse. These agreements were then translated into legislation.

A concrete example of this often overlooked dimension to the confiscation process is the two Mohaka-Waikare deeds and associated legislation of 1870. Following the battles of Omarunui and Petane (October 1866), near Napier, when a group of Pai Marire faithful, 'Hau Haus' in the language of the day, were overwhelmed by Crown forces and by the Crown's Māori allies, a very large slice of Hawke's Bay was confiscated by proclamation under the New Zealand Settlements Acts in 1867. The driving force behind the confiscation was Sir Donald McLean, head of the executive government of Hawke's Bay Province (McLean later repudiated confiscation, calling it "an expensive mistake"). ${ }^{19}$ Following the confiscation, however, the Mohaka-Waikare confiscation languished in confusion. The Compensation Court, given the impossible task of deciding under the confiscation legislation who was rebel and who loyal (a task its judges loathed), failed to even make

16 William Martin "Observations on the Proposal to take Native Lands under an Act of the Assembly" [1864] I AJHR E2 at 7-8.

17 Aborigines Protection Society to Grey, 26 January 1864 [1864] AJHR E2 at 16, as cited in Waitangi Tribunal The Taranaki Report (WAI 143, 1996) at 113.

18 See especially Nicholas Canny Making Ireland British, 1580-1650 (Oxford University Press, Oxford, 2003). Canny's book deals with plantation and settlement in Ireland during the Elizabethan period and under the early Stuarts, not with the Cromwellian and Williamite confiscations during the 1650s and after 1689. Other studies are TC Barnard Cromwellian Ireland: English Government and Reform in Ireland 1649-1660 (Oxford University Press, Oxford, 1975); TC Barnard "New Opportunities for British Settlement: Ireland, 1650-1700" in Nicholas Canny (ed) The Origins of Empire: Oxford History of the British Empire (Oxford University Press, Oxford, 1995) vol 1, 309; JG Simms, The Williamite Confiscations in Ireland, 1690-1703 (Faber and Faber, London, 1956).

19 McLean to JD Ormond, 1869, AGG-HB 1/1, Archives New Zealand, Wellington. 
an appearance in Hawke's Bay. ${ }^{20}$ McLean, who became Native Minister in the national or general government in 1869 , decided to deal with the matter by means of an agreement. This eventually took the form of a written deed, negotiated with the Hawke's Bay chiefs, the Mohaka-Waikare deed, which was given effect to in statute, the Mohaka and Waikare Districts Act $1870 .^{21}$ This statute, admittedly, is not one of the best-known enactments in New Zealand legal history. The pivotal point, however, is that the agreement was given effect to in statute. That is, the agreement itself needed a statute to make it effective as it lacked effectiveness of itself. And that is of itself a clue: that in some sense or other the Mohaka-Waikare agreement was not perceived merely as a selfexecuting contract but rather as something more like a treaty. Ordinary contracts do not need statutes, as they are effective of themselves, whereas treaties are not self-executing and have to be translated into statute to become effective, as is still the case with the Treaty of Waitangi itself. These events and their interpretation were considered fully in the Waitangi Tribunal's Mohaka ki Ahuriri Report ${ }^{22}$ and have now assumed an important role in negotiations of the present day as northern Hawke's Bay groups such as Ngāti Tu, Ngāti Kurumokihi and Ngāti Hineuru based in the upper Mohaka valley move into settling their historic issues with the Crown.

The Mohaka-Waikare deeds were not unique, and there were other examples. But I need to move on to the fourth, and the most interesting category of all, the regional political agreements. These were large-scale, comprehensive negotiated arrangements whereby regions which had de facto autonomy up to that time became part of the political formation which we call, for shorthand's sake, 'New Zealand'. They can be seen as a series of voluntary decisions to join in the project of state-building in this country upon terms. The New Zealand state did not emerge fully-formed overnight in 1840. For decades the mechanisms of government were tiny, and large parts of today's national territory were beyond its control. The quasi-federal system that was instituted in 1852 in which government was shared between the provinces and the 'general' government, based first at Auckland and then at Wellington, complicates the picture still further, as does the emergence of a competing sovereignty in the form of the independent autonomous King Country state in 1858 . The New Zealand Wars ended the autonomous Kingitanga state in the Waikato and consolidated the government's hold on the North Island interior. Nevertheless, for decades after the wars there were large parts of the North Island where the Crown's writ, as a matter of actual, day-to-day practice, still did not run. There were, in my view, four such areas (at least): (a) that part of Taranaki to the west of the Waingongoro river and centred on the community at Parihaka; (b) the autonomous King Country, or Rohe Potae; (c) the Rotorua region around lakes Rotorua, Rotoiti, Tarawera and

20 On the Compensation Court see RP Boast "'An Expensive Mistake': Law, Courts and Confiscation on the New Zealand Colonial Frontier" in Boast and Hill (eds) Raupatu, above n 14, 145, at 145.

21 On this process see RB Boast "An Expensive Mistake", ibid. The legality of these arrangements was scrutinised by the Privy Council in 1902: see Te Teira Te Paea v Te Roera Tareha [1902] AC 56 (PC).

22 Waitangi Tribunal The Mohaka ki Ahuriri Report (WAI 201, 2004). 
Rotomahana; and, (d) the very large Urewera region, mostly belonging to the Tuhoe people. (The last of these is of course the subject of the late Professor Judith Binney's Encircled Lands published last year.) $)^{23}$ As at 1880 these areas were still in effect independent. The first of these areas was suppressed, more or less forcibly, in 1881, when, mounted somewhat theatrically on a white horse, the Native Minister in the Hall Government, John Bryce - "honest John" to his contemporary admirers - led a force of 959 volunteers and 630 Armed Constabulary into Parihaka and brought its independence to an abrupt end. These events are well-known, and I will not comment about Parihaka further here. ${ }^{24}$ But with respect to the others a rather different, and somewhat less depressing, process eventuated. In each case there was a long process of negotiation leading to an agreement.

I have mentioned the King Country process already, and the late Professor Binney's new book has made the story of the Urewera negotiations of 1895-1896 familiar to a wide audience. I can therefore focus on an area that might perhaps be less familiar, that is to say the Rotorua region. ${ }^{25}$

The notion that the Rotorua region as at 1880 was still more or less autonomous and selfgoverning may come as something of a surprise. For one thing, the Arawa iwi and hapu had mainly fought their way through the hard years of the New Zealand Wars as allies of the Crown, reflecting to some extent the structure of existing iwi politics in the Bay of Plenty and the Waikato. This is fairly widely-known, as is the fact that the Rotorua region, far from being an enclosed Māori district like the King Country or Te Arawa, was well-known throughout the country and was already an international tourist destination. Before the construction of a rail link to Rotorua, tourists usually travelled by steamer to Tauranga and then travelled by coach to Ohinemutu, a two-day trip, and then visited the Pink and White Terraces, Orakeikorako, Whakarewarewa and other famous sites of what in those days was called the "Hot Lakes" district. But what is less well-known is that politically this region was governed not from Wellington but by local Māori councils, including Ngāti Whakaue's "great council" based at Ohinemutu. The Native Land Court was banned from the region and while European storekeepers and businessmen were welcome to live there, they lived on Māori customary land. ${ }^{26}$

23 Judith Binney Encircled Lands, above n 11.

24 There is abundant literature on Parihaka. See Dick Scott Ask That Mountain: The Story of Parihaka (Southern Cross Books, Auckland, 1975); Hazel Riseborough Days of Darkness: Taranaki, 1878-1884 (Allen and Unwin, Wellington, 1989).

25 On the Fenton agreement and its background see Richard Boast Buying the Land, Selling the Land, above $\mathrm{n}$ 8 , and references therein cited.

26 On the context of the Fenton Agreements at Rotorua see Richard Boast Buying the Land, Selling the Land, above n 8, at 169-173. The Waitangi Tribunal has analysed the Fenton Agreements and the Thermal Springs Districts Acts: see Waitangi Tribunal He Maunga Rongo: Report on the Central North Island Claims (WAI 1200, Wellington, 2008) at 282-365. See also WAI 1200 document A70, Kathryn Rose The 
In 1880 the Government, anxious about the not altogether respectable tourist industry of the region, and hoping to replace it by something a bit more genteel and under government control, sent the Chief Judge of the Native Land Court, Francis Dart Fenton, to Rotorua to talk to the chiefs and to work out some kind of agreement with them. Fenton arrived at Ngāti Whakaue's large village at Ohinemutu in November 1880. Here he negotiated a remarkable agreement with Ngāti Whakaue's Komiti Nui (Great Committee) at the famous meeting house Tamatekapua. ${ }^{27}$ The document was worked out in the Māori language. Fenton could speak and write the language fluently and his various Māori-language drafts are still on the file. This agreement is known to this day as the Fenton agreement and it is certainly well-remembered by Ngāti Whakaue.

What did the respective parties hope to achieve? Clearly some of the Rotorua chiefs wanted to encourage economic growth in their region and to see better schools provided for the children of the region. The idea of drawing up a formal written document appears to have originated principally in Fenton's own very fertile brain. What he wanted to gain for the Government is not clear. The Government had given him a very free hand. Fenton stayed at Ohinemutu for about a fortnight, and seems to have spent that time mainly at Ohinemutu, and although in his report back to Wellington he said that he visited the 'neighbouring tribes' the only other Arawa iwi mentioned specifically by him is Tuhourangi. The Fenton agreement was with Ngāti Whakaue only, it appears (they being probably the largest of the Arawa groups). Fenton did in fact draw up a separate and much less comprehensive agreement with the neighbouring Tuhourangi iwi, but he informed the government it "need not be noticed". ${ }^{28}$

The agreement was all about the arrangements for the new town of Rotorua. After a survey, to be carried out by the chief surveyor, the Native Land Court was to sit at Rotorua and adjudicate on the block known as Te Pukeroa or Pukeroa-Oruawhata, a block of land that accounts for practically all of the modern city of Rotorua. Allowing the Land Court into their region was of course a major concession on the part of the Ngāti Whakaue leadership. The village of Ohinemutu was to be left out of the survey and investigation by the Court. Following the survey, the plan was for PukeroaOruawhata to be cut up into sections and leased out on long-term leases. Special provision in the Fenton agreement was made for the hot springs and thermal areas. For example cl 3.6 of the agreement stipulated that: "All the medicinal waters within the Town shall be Public Reserves under the management of the doctor, who may make laws regulating their use." The final text of the agreement was endorsed on the back by the Governor General, where one can still see his note and

Fenton Agreement and Land Alienation in the Rotorua District in the Nineteenth Century (Crown Forestry Rental Trust, 2004)

27 The Komiti Nui is described in Fenton's report of 18 December 1880 (MA 13/79, Archives New Zealand, Wellington). He notes here that he found at Ohinemutu "a regularly organised head body with Chairman, Secretary, and officers".

28 Fenton to Rolleston, 14 February 1882 (MA 13/79, Archives New Zealand, Wellington). 
signature stating that he hereby contracted with Ngāti Whakaue on the terms set out in the document. ${ }^{29}$ And the agreement, once again, was given effect to in statute, the government perhaps taking some very large liberties however, this being the Thermal Springs Act of 1881.

So, what do we call this text? What is it? Is it misleading to think of it as a treaty in some sense?

The scheme itself was a very beguiling and innovative one and it began well. PukeroaOruawhata made its way through the Native Land Court sitting at Ohinemutu in the first half of 1881, the hearings taking nearly six months (on and off). ${ }^{30}$ The hundreds of pages of evidence taken can still be read in volume one of the Land Court's Rotorua Minute Books. Judge Symonds heard the case with Fenton watching events very closely behind the scenes. Practically every Arawa iwi claimed an interest in the block, now very valuable, but Symonds duly awarded it to Ngāti Whakaue. When the first auction of the Rotorua leases took place in Auckland it went off very successfully and there were hopes that large sums of money would soon be pouring in to Rotorua. Fenton is regarded on the whole as a fairly cold and austere person, so it comes as a surprise to learn that at the scene of the auction he and a group of Te Arawa chiefs were observed performing a haka together at the back of the hall in sheer delight at the success of the project. But unfortunately the scheme soon began to unravel. There were disputes about the legal nature of the agreement. Some of the tenants declined to pay rent and there were legal difficulties with collecting it. Then in 1886, nature, always a force to be reckoned with in our volatile isles, as recent events have reminded us all, struck in the form of the Tarawera eruption, which caused heavy loss of life, destroyed the Pink and White Terraces, and blanketed the Hot Lakes region in volcanic mud and ash. No one wanted to buy leasehold lands at Rotorua any more, or pay their rents to Ngāti Whakaue. The latter, discouraged, sold Pukeroa-Oruawhata to the government. This turned the Crown into the largest landowner at Rotorua, contributing to the oddly governmental aura the town had till recently, with its Government Gardens, Government Tourist hotels, the Tourist Department's round tour to Rotomahana and Tarawera, the model village at Whakarewarewa (this being a highly sanitised model pa for tourists to visit), and with some of the thermal areas in Crown ownership. The Crown's hopes to create a Baden Baden or Cheltenham of the South Seas also came to naught. So much for the Rotorua story. (I admit to being something of an aficionado of the unique city of Rotorua and its interesting history, as may perhaps be apparent.)

29 Endorsed on the back of the Māori-language text of the agreement there is the following endorsement, executed by the Governor-General (Sir Arthur Gordon) (see MA 13/79, Archives New Zealand, Wellington):

In pursuance of the Thermal Springs District Act 1881, and in exercise of the powers conferred on me by the 5 th section of the said Act, I hereby contract with the Tribe of Ngati Whakaue in terms of the above written instrument. Dated 16th day of February 1882. Signed: Arthur Gordon, Governor.

30 See the Native Land Court's Pukeroa-Oruawhata judgment 13 at (1881) 1 Rotorua MB 344 
The last of the great regional pre-emptive negotiations was that between Tuhoe and some of the other Urewera tribes, such as Ngāti Whare and perhaps Ngāti Manawa, that took place in Wellington in 1895. Representing the Crown side of the table was the Prime Minister, no less, Richard John Seddon, ably assisted by James Carroll (Timi Kara) of Ngāti Kahungunu. ${ }^{31}$ The outcome of the prolonged negotiations was again a legislative arrangement which brought the de facto independence of the region to an end, although in the case of Tuhoe they insisted that the Native Land Court stayed out of their area and were to some degree able to carry their point. In her wonderful book Encircled Lands Professor Binney stated that the 1896 Act which legislated the negotiations with Tuhoe "is unique in Aotearoa New Zealand, for the Urewera is the only autonomous tribal district that was recognised in law". ${ }^{32}$ That is probably right - although I am not sure that Ngāti Maniapoto would unreservedly agree - but nevertheless in my view the negotiations that took place with respect to the Rohae Potae, Te Urewera, and Rotorua have much in common and stand together as a recognisable group. Binney observes too that the 1896 Act for Tuhoe "terminated" the "de facto autonomy" of Tuhoe; by "promising internal self-government, [it] brought the Urewera under the Crown's overarching authority". ${ }^{33}$ This is generally the case with the Rohe Potae/King Country negotiations; perhaps less so for Te Arawa.

That there is a wealth of texts, is, as I hope I have shown, clear. I hope so far that I have demonstrated not just that, but also that there is a hierarchy or range of negotiations, with some of them being much more treaty-like than others. But I still have not resolved the pivotal question: are they treaties? And - if they are - what then of the Treaty of Waitangi? How do we fit this constellation of other agreements around it?

One might say that in terms of formal law, obviously none of these agreements or whatever else they are, are treaties as that term is understood in modern international law, because treaties are agreements between entities which have international legal personality. Thus a classic work of international law defines treaties as "agreements, of a contractual character, between States, or organisations of States, creating legal rights and obligations between the Parties". ${ }^{34}$ One could spend a long time analysing and critiquing this highly formalist definition by a great international lawyer, but it does demonstrate that in a rigorous or classical conception of international law the Tuhoe or King Country agreements are not treaties as neither Tuhoe nor the King Country chiefs were states, or at least were not recognised as such. It should be added that probably the New Zealand colonial government was, in strict point of law, not a state either: in fact the first international treaty that

31 On the negotiations see Judith Binney Encircled Lands, above n 11, at 328-395.

32 Judith Binney Encircled Lands, above n 11, at 4.

33 Ibid, at 404.

34 Lassa Oppenheim (Hersch Lauterpacht ed) International Law: A Treatise (8th ed, Longman, London, 1955) at 877 . 
New Zealand signed as a state was, I believe, the Treaty of Versailles. ${ }^{35}$ Neither side (arguably) qualified. Nor, in any event, can the Courts sit in judgment as to whether the Crown has sovereignty over the whole country. However, how these other agreements are interpreted will make no difference when it comes to the legality of the Crown's sovereignty over the whole country or to the fact that it has title (imperium) over the whole of the national territory. ${ }^{36}$ These answers, correct perhaps in terms of legal formalism, fail to resolve the matter very satisfactorily when it comes to understanding the history of our country.

A counter-example is the United States - as far as international law was concerned, following the Louisiana purchase and the peace of Guadalupe Hidalgo of 1848, the United States was the sovereign power over most of the territory that it occupies today, but still as a matter of American public law agreements with the Indian nations within that territory are treaties for the purposes of American constitutional law. But then again the United States is a complex political entity of multiple sovereignties and the Indian nations have a status within that system of 'domestic dependent nations' (to quote the much-cited phraseology of Chief Justice John Marshall in Cherokee Nation v Georgia). ${ }^{37}$ Māori political formations (whether iwi or hapu) do not have that status, and in fact do not even have a corporate status of any kind as such in New Zealand law. Even so it is surely suggestive and important that the United States unhesitatingly classifies agreements between the indigenous nations of North America and the federal government as treaties. So, for that matter, does Canada.

Another point to make here is that the very narrow definition of what a treaty is that I gave earlier does not necessarily reflect 19th century perceptions. This point has been well made in a fascinating new book by Bain Attwood about what is probably Australia's only possible candidate for a treaty, that is the document drawn up by John Batman on behalf of the Port Phillip Association in 1835 with the aboriginal people of what is now the location of the great city of Melbourne. This 'treaty' has long been seen as an isolated and foolhardy enterprise which was soon disallowed. But Attwood has argued that Batman's treaty was a real act of treaty-making, that it can validly be called a treaty, and has drawn attention to the fluidity of the meaning of a treaty and its very pervasiveness.

35 New Zealand acquired Dominion status in 1907, but the exact meaning of the term "Dominion" was unclear. In 1919 the Prime Minister of New Zealand, WH Massey, signed the Treaty of Versailles along with representatives of the other Dominions as part of a British Empire delegation.

36 Such questions are treated by the courts as non-justiciable: see for example Mabo v Queensland (No 2) (1992) 175 CLR 1 at 31 per Brennan J. In New Zealand the courts accept the provisions of the New Zealand Boundaries Act 1863 (UK) as authoritative: see Berkett v Tauranga District Court [1992] 3 NZLR 206 (HC) at 11 per Fisher J. The latter case also appears to accept that the Crown's proclamations of sovereignty over New Zealand in 1840 are unchallengeable in any event: see Berkett v Tauranga District Court at 213, and also the dictum of Richardson J in New Zealand Māori Council v Attorney General [1987] 1 NZLR 641 (CA) at 690 .

37 Cherokee Nation v Georgia (1831) 30 US 1 at 16. 
Europeans, Attwood writes, "made agreements with indigenous peoples in South and West Asia, North Africa and North America; and during much of the nineteenth century they continued to treat with indigenous peoples in North America, Asia and the Pacific." In fact, Attwood writes, "[i]t could even be argued that treaty-making was the norm." 38 Indeed it was.

Finally there are two sides to any bargain. Even if the Crown did not necessarily think that it was doing anything at a level of high constitutional and legal significance, it does not follow that Ngāti Maniapoto, or Raukawa, or Ngāti Whakaue, or Tuhoe, or Ngāti Whare, thought the same thing. Today these agreements are certainly well-remembered, as I can attest to from having been told this myself, or from oral and traditional evidence I have heard given at Waitangi Tribunal hearings.

I really believe then that we do have a genuinely difficult legal and constitutional problem here, and maybe we need some kind of new legal language to characterise the realities of our history. If the King Country agreement is not a treaty - and, in fact, (as at 1880) the King Country was a de facto autonomous state, and the New Zealand government was a de facto sovereign polity independent of the British government - then what might it be? To call it an agreement may seem sufficient, but what sort of agreement? Just a contract? But contracts are typically self-executing and enforceable as such, and the King Country agreement would not be - is it then merely a political deal with no kind of legal quality attached to it whatever?

We are not alone in facing this puzzle. A prominent Argentinian legal historian, Abelardo Levaggi, professor at the Faculty of Law at the University of Buenos Aires, has noticed a remarkable disjuncture between political and constitutional theory and actual state practice in his country. ${ }^{39}$ Like all the Latin American republics, Argentina has a very strong sense of a clear sovereign authority over the national territory, deriving from the revolutionary struggle for independence from Spain and from the republican ideals deriving from the French Revolution which were part of the mindset of 19th century Latin American republican leaders like San Martin, Sucre, and Bolivar. That is the theory, and thus there is no room for there being treaties between the government of Argentina and the Indian nations living within the national territory. Yet - just as in New Zealand - in practice Argentine republican governments carried out such negotiations and concluded such agreements all the time. In his remarkable book Paz en la Frontera (Peace on the Frontier) Levaggi rescued all these agreements from oblivion and set them all out systematically for

38 Bain Attwood Possession: Batman's Treaty and the Matter of History (Miegunyah Press, Melbourne, 2009) both quotes at 13

39 Abelardo Levaggi Paz en la Frontera: Historia de las Relaciones Diplomáticas con las Comunidades Indígenas en la Argentina (siglos XVI-XIX) (Universidad del Museo Social Argentino, Buenos Aires, 2000). For the context of relationships between the Crown and indigenous peoples during the later phases of the Spanish colonial empire see generally David Webe Bárbaros: Spaniards and their Savages in the Age of Enlightenment (Yale University Press, New Haven and London, 2005). 
everyone to see. There are hundreds of such agreements. Writing of colonial Argentina, Levaggi notes that "without renouncing their ultimate objective of achieving a complete domination of the [national] territory" - any more than colonial New Zealand governments did - 19th century Argentinian governments used a temporary ad hoc law based on the law of nations relying on the internal treaty as its "fundamental instrument". ${ }^{40}$ In Levaggi's words again, "[o]n the one hand it [Argentina] did not recognise that the indigenous groups were legal entities of a national character, while, on the other, it concluded peace treaties with them, which carried with them such recognition implicitly." 41 Can a state fairly claim that the party it is engaged in treaty-making with has no capacity to enter into treaties? As Levaggi puts it,"[l]a conducta del Estado argentino ... fue, ciertamente, contradictoria" ("the conduct of the Argentinian state was undoubtedly contradictory"). And the same can be said of the colonial New Zealand state. Moreover - as he also says of Argentina, which is equally true of New Zealand - the treaties made in Argentina "were at first denied the same status as those in North America, and then were subsequently scorned, nullified, were lost and forgotten, as if they had never existed in the first place". ${ }^{42}$ In New Zealand it is the government, however, that has been forgetful. These arrangements have not been forgotten by Te Arawa, Ngāti Maniapoto, Raukawa, Tuhoe and other groups who participated in them: far from it. That is why the problem is rapidly moving from one of legal history and the search for constitutional languages to the realities of politics and the historical settlement process as it currently operates. But then there is a difference with Argentina too: we have the Treaty of Waitangi, and Argentina does not have that or anything equivalent to it.

For various reasons the Treaty of Waitangi has been elevated as a result of court decisions, statutes, and state and public authority practice into a kind of constitutional standard. There have been many sound reasons for doing this. One has to accept, however, that many iwi and hapu in this country do not have strong traditions about the Treaty of Waitangi and did not in any real sense assent to it. As a matter of legal formalities that arguably does not matter - all are deemed to have participated in some way. Nor should we forget Claudia Orange's caution that the Treaty of Waitangi was not signed overnight: the process of adhesion to the Treaty of Waitangi was a long and gradual process, longer and more gradual in fact than the drawn-out process of taking the various texts around the country. ${ }^{43}$ That aside, and not wanting to overstate things, to a number of

40 Levaggi, above n 39 at 19.

41 Ibid, at 563 [author's translation].

La conducto del Estado argentino, a diferencia de la Corona española, fue, ciertamente. contradictoria. Por un lado, no reconoció que los indígenas formasen comunidades jurídicas con categoria de nación (no Estados soberanos), y, por el otro, había firmado con ellos tratados de paz, que llevaban implícito ese reconocimiento.

42 Levaggi, above n 39, at 561 [author's translation].

43 Claudia Orange The Treaty of Waitangi (Allen and Unwin, Wellington, 1987) at 89. 
groups, such as Ngāti Maniapoto, Tuhoe, and Te Arawa, it is their own agreements with the Crown that really matter, or perhaps which really have a place in their hearts.

The Waitangi Tribunal and the negotiations of the present day are now the arenas that count for practical purposes, but the status of these earlier agreements has come up on earlier occasions. In 1953 Dr AH McLintock, a distinguished scholar and newly appointed parliamentary historian, was commissioned to write a report as to whether it was true, as Ngāti Maniapoto and other iwi claimed, that a "sacred pact" had ever been entered into between the tribes and the Crown in the 1880s. The context for this inquiry was actually that of liquor licensing: the King Country as at 1953 was a 'dry' area and Māori wanted it to stay that way, arguing that the prohibition of the sale of liquor was one of the solemn undertakings that the Crown agreed to in the negotiations that took place from 18821885. McLintock concluded that there was no "solemn pact or pledge" binding on New Zealand governments. ${ }^{44}$ That finding can certainly be said to be a conclusion of law as much as it is of history, and one which gave no weight to Maniapoto tradition as to what had been agreed. However, the government accepted McLintock's findings and the King Country was duly opened to the sale of liquor. The ironies of all that are too obvious to need pointing out.

The Waitangi Tribunal, in the process of drafting its reports and recommendations, is governed by its empowering statute, which directs its attention to the Treaty of Waitangi. That is the Tribunal's mandate from parliament, one which it cannot change. In a sense it matters not whether any particular claimant group before it actually had much to do with the Treaty of Waitangi. Nevertheless groups do invoke these other agreements, usually as a way of constructing an argument that some particular group has a special or distinctive status that differentiates it from other groups.

One of the issues discussed in a recent important Waitangi Tribunal report, Kaipara ${ }^{45}$ was whether there was an 'alliance' between the Crown and Ngāti Whatua, one of the principal iwi of the Auckland isthmus. An alliance, obviously, arises only by agreement. Counsel for Ngāti Whatua argued that this alliance was "entered into as a mutually beneficial arrangement imposing obligations on both parties" in 1840, quite separately that is from the Treaty of Waitangi. Ngāti Whatua argued that Ngāti Whatua had kept its part of the bargain by making land available to the Crown, by "remaining loyal to the Crown and working in cooperation with Crown institutions"46 and by making particular gifts of land to the Crown. On the other hand it was said that the Crown had failed to keep to its side of the bargain by "failing to ensure that Ngāti Whatua were given

44 See AH McLintock "Liquor in the King Country" [1953] IV AJHR H25 at 58. McLintock was a wellknown and respected historian, best-known as the author of The History of Otago (Otago Centennial Heritage Publications and Whitcombe and Tombs, Dunedin, 1949).

45 Waitangi Tribunal Kaipara Report (WAI 674, 2006).

46 Ibid, at 153. 
political or legal equality, by undermining Ngāti Whatua's ability to exercise tino rangatiratanga"47 and neglecting "to provide the promised services, infrastructure, and settlement at a time when Ngāti Whatua were in a position to benefit from these".

Competing expert evidence on the 'alliance' was presented by two very capable historians: Philippa Wyatt on behalf of the claimants and Dr Donald Loveridge on behalf of the Crown. The evidence for the 'alliance' was largely circumstantial in that it was inferred from the circumstances of the early settlement of Auckland, rather than on the basis of any evidence of negotiations and an agreement, and there was no written text to which the claimants could point. (This was quite different from, say, Rotorua.) The Tribunal was unconvinced that there ever was an 'alliance' as such, and the Crown for its part argued strenuously that such had never existed. But the Tribunal also emphasised that any suggestion that the Crown had particular obligations to any one iwi arising from an alliance - or indeed from any other kind of pact - is "highly problematic". Such agreements do not, in the Tribunal's view, actually add anything to the Treaty of Waitangi, which, as interpreted and applied by the Tribunal, suffices equally well for all: ${ }^{48}$

The Treaty [of Waitangi] provides the same protections and guarantees to all Māori authorities and groups. Even if a special relationship between the Crown and a particular Māori group could be demonstrated to have existed, such a relationship should have no bearing on the Crown's Treaty responsibilities to that group.

This seems to overstate the case. Surely the Tribunal cannot mean that something as long and complex as the Rohe Potae negotiations, for example, count for nothing.

Last year (2010) the Waitangi Tribunal issued that part of its Te Urewera report that dealt with, amongst other issues, the 1895 negotiations and the legislation of 1896. The Tribunal discussed the negotiations fully, but focused mainly on the issue as to whether the Act of 1896 actually reflected what had been agreed in the negotiations of 1895. That is of course an important issue in its own right. The Tribunal characterised the Urewera agreement of 1895 and the Urewera District Native Reserve Act as a "constitutional first", and found that it was of "constitutional significance". ${ }^{49}$ The Tribunal saw the events of 1895-1896 as bringing the peoples of Te Urewera and the Crown into a relationship based, however, on the Treaty of Waitangi: as a kind of delayed accession. Whether this kind of analysis is entirely satisfactory is a matter I will not go into here. The Urewera Inquiry certainly does indicate the importance of the issue of "other" agreements (or treaties) and the importance of devising an intellectually satisfactory method of dealing with them and integrating them with the existing legal discourses surrounding the Treaty of Waitangi. This is likely to become

47 Ibid, at 164.

48 Ibid, at 97.

49 Waitangi Tribunal Te Urewera Pre-Publicaton Text Part II (WAI 894, 2010) at 482. 
even more important with the Tribunal's Rohe Potae or King Country inquiry, set to move into its main hearings phase next year.

It is clear, then, that the Crown and Māori have a long history of entering into agreements. This is not a process that has come to an end. In fact it has, if anything, been re-energised over the last twenty years, as New Zealand, along with a number of other countries, has embarked on a long and difficult process of the negotiation and settlement of a range of historic claims. Making agreements and deals is one aspect of the long history of cultural mixing and engagement that has long characterised the history of this country. ${ }^{50}$

I have chosen to dwell on this issue not in order to raise complications for the claims or Waitangi Tribunal processes, but simply because it seems to me that it is beneficial and interesting to think again about our own history, and maybe to develop a sense of the complexity and variety of our own history. History is never fixed but always needs to be rethought afresh. And before drawing conclusions we need to reconsider what happened.

How to progress work in this area? What I want to suggest - a modest and humble project, but (I believe) a good start - is that the time is now ripe to collect together all the basic materials and publish them for all to see. The old pre-emptive deed purchases which were published in the 19th century have been digitalised and remain fairly serviceable. Turton's Deeds is all too familiar to those of us who work in this field. But the documentation relating to the peace negotiations, confiscation agreements, and regional political arrangements (my second, third, and fourth categories), has never been collected together between two covers and my suggestion is that it ought to be.

As I hope I have shown, the legal and constitutional situation is complicated, and much more interesting than is often supposed. Our constitutional and political system looks simple on the surface, but this masks a much more ambiguous and complicated reality. That the Crown would conduct high-level negotiations between a delegation of chiefs from a de facto independent zone, incorporate the agreement into a written text, and then translate that text into law as late as 1896, must reveal something of real significance about the true history of the surprisingly intricate polity

50 A focus on cultural mixing and globalisation in the Early Modern period is characteristic of French historiography relating to European (especially Spanish and Portuguese) colonial expansion, insights which seem to me to be equally applicable to British colonisation in the Pacific in the nineteenth century. See especially Carmen Bernand and Serge Gruzinski Histoire du Nouveau Monde: Les métissages (1550-1640) (Libraire Athème Fayard, Paris, 1993) (translated into Spanish as Historia del Nuevo Mundo: Los mestizajes (1550-1560) (Fondo de Cultura Económica, México DF, 1999)); Christian Duverger Cortés (Taurus, México DF, 2005); Christian Duverger El primer mestizaje: La clave para entender el pasado mesoamericano (Taurus, México DF, 2007); Serge Gruzinski Les quatre parties du monde: Histoire d'une mondialisation (Éditions de la Martinière, Paris, 2004) (translated into Spanish as Las cuatro partes del mundo: Historia de una mundialización (Fondo de Cultura Económica, México DF, 2010)). It is much to be regretted that these pivotal books have not so far been translated into English. 
in which we all live today. The past no less than the future is full of possibilities. To end, I can only quote Allen Curnow: ${ }^{51}$

\author{
And whatever islands may be
}

Under or over the sea,

It is something different, something

Nobody counted on.

51 Allen Curnow "The Unhistoric Story" in Robert McDonald Chapman and Jonathan Francis Bennett (eds) An Anthology of New Zealand Verse (Oxford University Press, Oxford, 1956) 150. 